\title{
Quantity and the Three-Syllable Window in Dutch Word Stress
}

Marc van Oostendorp*

Meertens Instituut, Amsterdam \& Leiden University

\section{Abstract}

This paper considers the state-of-the-art in the (generative) study of Dutch word stress. In the past 25 years, consensus has been reached on a number of properties of the Dutch stress system, such that it obeys the so-called three-syllable window and that it is quantity sensitive. However, not all of these arguments are equally convincing in the light of modern developments in phonological theory, in particular since experimental data on native speakers' intuitions are missing. Although there is strong evidence for quality-sensitivity (in particular to the quality of schwa), the evidence for quantity-sensitivity is not so strong, given that the main sources of loanwords (which are usually argued to be quantity-sensitive) themselves are quantity-sensitive.

\section{Introduction}

The representation of word stress in Dutch has been a topic of quite some research in generative phonology. The generally accepted view is that this stress system is not very different from that of other West-Germanic languages such as German (Wiese 2000), English (Hammond 1999) and Frisian (Visser 1997). For all these languages, it has been claimed that main stress falls on one of the last three syllables of the word, and that it is partly unpredictable, and partly determined by phonological regularities such a syllable quantity.

In this article, I will give critical evaluation of the literature, with an emphasis on Van der Hulst (1984), Trommelen and Zonneveld 1989, Kager (1989), Nouveau (1994), Van Oostendorp (1997) and Gussenhoven (2009). As far as I can tell, almost all major publications are based on the assumption that Dutch has a quantity-sensitive stress system, i.e. the difference between light and heavy syllables is somehow taken into account in the computation of stress. In generative terms, this meant that quantity-sensitivity was considered to somehow be part of the native speaker's knowledge of the stress system. ${ }^{1}$

I show that the empirical basis for this assumption has never been strong. Certain regularities exist, but (i) there are 'exceptions' to these as well, and (ii) at least some of the regularities find an explanation in other factors, e.g. in the fact that most borrowings themselves have been taken from languages with a quantity-sensitive stress system. If the regularities are not very strong and if there is no reason to assume that speakers have knowledge of these regularities, there is little reason to try to describe them in phonological terms - at least if we believe that the ultimate goal of phonology is to describe knowledge of sound systems.

With respect to point (i) just mentioned, the reasoning has usually been that the exceptions should be marked in the lexicon. Also the more recent OT literature on Dutch stress assignment (Nouveau 1994; Oostendorp (1997); Geerts 2008; Gussenhoven 2009) has adopted this assumption. The methodological question which arises in this case is how we decide which forms are the rule and which are the exceptions and, if all 
patterns are possible, why we need to assume that there is a process of 'assigning' stress at all.

Implicitly, the answer to this has usually been to relegate as much work to the grammar as possible. Underlying this assumption is one of representational economy: the best account is one which posits the smallest number of specifications in the lexicon. This idea of economy seems mostly abandoned, for instance in the advent of theories such as Government Phonology and Optimality Theory, which makes the whole enterprise of devising an algorithm for assigning mostly unpredictable stress spurious. The literature on stress, which stems mostly from the 1980s and 1990s, has so far not been reevaluated under this light, however.

The structure of this paper is as follows. In Section 2 I discuss the so-called three-syllable window, the claim that Dutch stress is on one of the last three syllables of the word. Subsequently, we move to various types of weight which have been assumed to be relevant for stress assigment. Section 3 discusses the role of schwa and the distinction between light and heavy syllables. Section 4 provides an overview of the relevant data on so-called superheavy syllables. Section 5 closes off with a discussion on the way in which we should evaluate at the first sight rather mixed results on quantity-sensitivity in Dutch.

\section{The Three-Syllable Window}

The examples in (1) show that Dutch stress is at least partly lexical: These pairs of words differ from each other only in the location of stress, not in their segmental content or any other lexical property.

\section{(1) kanon 'gun' [ka'non] canon ['kanon] 'norm'}

If Dutch stress were indisputably a purely unpredictable property of words, there obviously would not be a lot of discussion about it. Every word would have its specification of a stress position in the lexicon, and the phonological grammar could stay silent. However, all scholars on Dutch of the past decades seem to agree that there are several restrictions as to the position of primary stress (Booij 1995; Daelemans et al. 1994; Geerts 2008; Gussenhoven 1993, 2009; Kager 1989; Kager and Visch 1983; Kager et al. 1987; Kager and Zonneveld 1986; Kooij 1978; Lahiri and Kooreman 1988; Langeweg 1988; van Marle 1980; Neijt and Zonneveld 1982; Nouveau 1994; van Oostendorp 1997; Rietveld et al. 2004; Trommelen 1991; Trommelen and Zonneveld 1989, 1999; Visch and Kager 1984; Van Zonneveld 1984; Zonneveld 1993, 2003). The strongest consensus is probably on the claim that Dutch is subject to a three-syllable window, familiar also from many other Indo-European languages. Stress outside of this window, i.e. on the preantepenultimate syllable of the word, is indeed rarely attested:

\section{(2) *['makaroni]}

In spite of this general consensus, it is hard to find clear evidence that this window plays or has ever played an active role in the synchronic phonology of Dutch. As is well known, (West-)Germanic had systematic initial stress, so we might expect long words of this origin to have shifted; but it is difficult to find monomorphemic West-Germanic forms which have the required length. Trommelen (1989) argues that at least verbs tend to have at most one full vowel plus an optional schwa-headed syllable. Also longer nouns are borrowed from other languages. The relevant words in contemparary Dutch thus have all been 
loanwords at some stage. The original West Germanic pattern changed under the influence of Latin or French or other Indo-European languages, in which the lexicon respects the three-syllable window already. The macaroni example in (2), for instance, is from Italian, in which all words except for the third person plural of some verbs respect the window (Krämer 2009): in order to get a window violation in the Dutch word, we would have to disrespect the Italian original and there seems little reason to do so.

As a matter of fact, there are two known classes of exceptions to the generalisation. The first consists of toponyms such as Scheveningen, Amerongen and Wageningen; the second is a class of Latin grammatical terms such as infinitief, accusatief and nominatief which all have initial stress. Admittedly, these two classes are small, but there is no specific reason to see these words as somehow not belonging to the Dutch lexicon or as being more foreign to it than many of the trisyllabic words. Actually, a CELEX search ${ }^{2}$ shows a few more individual examples:

(3) reutemeteut 'caboodle', ammelaken 'table cloth', tingeltangel 'honkeytonk', Erlenmeyer 'Erlenmeyer flask'

The list is obviously not very long, two of the words have some reduplicative quality to them (however that may be interpreted from a theoretical point of view), ammelaken is a word which was unknown to the author of this article and which may have a compound-like quality to those who do know it, and erlenmeyer is eponymous - while names have been argued to have a separate stress pattern.

The crucial argument that Dutch respects the three-syllable window thus is that exceptions may be ignored by phonological theory as long as they are few in number. It is not so evident, however, what this argument is based on. In order to make it precise, let us assume a concrete analysis of Dutch stress, for instance within Optimality Theory. The three-syllable window could be made to follow from the (plausible) assumptions that Dutch has trochaic feet, ${ }^{3}$ that stress is typically on the rightmost of these feet, and finally that the last syllable can be 'extrametrical' (not parsed into a foot), or 'catalectic' (i.e. empty, so that a word ending in a phonological bisyllabic trochee ends in a stressed syllable phonetically). This complex will give us the impossibility of preantepenultimate stress allowing all other possibilities: ${ }^{4}$

(4)

\begin{tabular}{|l|c|c|}
\hline makaroni & STRESS RIGHTMOST FOOT & PARSE-SYLLABLE \\
\hline ('maka)('roni) & & $\mathrm{W}^{*}$ \\
\hline ('maka) (roni) & & \\
\hline
\end{tabular}

But we somehow have to include words like infinitief into the picture. One way to do this would be to mark stress on this word and assume that faithfulness to this marking is dominant: ${ }^{5}$

(5)

\begin{tabular}{|l|c|c|c|}
\hline 'infinitief & FAITHFULNESS & $\begin{array}{c}\text { STRESS RIGHTMOST } \\
\text { FOOT }\end{array}$ & PARSE-SYLLABLE \\
\hline a ('infi)nitief & & & $*$ \\
\hline $\mathrm{b}$ ('infi)(nitief) & & $\mathrm{W}^{*}$ & $\mathrm{~L}$ \\
\hline c (infi)('nitief) & $\mathrm{W}^{*}$ & & $\mathrm{~L}$ \\
\hline
\end{tabular}


Obviously, however, as soon as faithfulness outranks everything else, we are no longer really saying that there is a three-syllable window in the language. The constraints are there, but they are low-ranked, as in any language which does not satisfy them at all. One way out would be to assume that this ranking is specific for words such as infinitief, etc. (for instance because there is a cophonology applying only to grammatical terms and a few other words). The issue is, however, that it is not clear what would be gained by this latter move as compared to the assumption that faithfulness is dominant for all words, and it just happens that most words have stress somewhere on one of the last three syllables. In other words, although it is clear that there is a statistical tendency of avoiding preantepenultimate stress, it is not clear why this should be turned into an absolute truth, also because there is an alternative explanation which may be even more suitable for the pattern at hand: the words have kept their original stress pattern from the source language.

Crucial evidence would come from the way in which loanwords from languages without a three-syllable window are treated, but I have not been able to find an uncontroversial instance of this in the literature. Furthermore, showing that words from those languages get regularized to e.g. penultimate stress, would not be sufficient. It could be that penultimate stress simply is the default (that definitely seems the most likely position for such a status), so that we need to show that loanwords never get regularized to antepenultimate or ultimate stress. As far as I am aware, evidence about this is lacking.

Another type of evidence would be alternations such as we find for instance in Greek. In this language, if we combine a stem that has antepenultimate stress with a clitic or a suffix, the stress shifts [in the case of clitics, the stress on the noun is kept as some kind of secondary stress, see $(6 a-b)$; this is not the case for the inflectional suffix in $(6 d)]$ :

(6) a. góndola (id) > gondolá-mu 'my gondola'

b. o jítonas 'the neighbour' $>$ o jítonás mas 'our neighbour'

c. cf. stafida $>$ stafida-mu (without stress shift)

d. to máthima 'the lesson' > to mathímatos 'of the lesson'

Dutch lacks any alternations of this type. This should not be counted as evidence against a three-syllable window, since there simply are also no clitics or suffixes forcing violation of this putative constraint. The evidence is thus completely neutral on this point. But the lack of alternations of this type would make it definitely hard for a language-learner to detect the activity of the putative constraint.

The little evidence we do have in the literature concerns a study by Nouveau (1994) on the acquisition of stress, where the author used nonsense words to test children's knowledge. Two of these nonsense words had the required length (both of them were four syllables long). Two parts of Nouveau's study are relevant for our present purposes. In the first place, Nouveau did a 'pretest' with 20 adult informants, who were asked to read the words aloud. The stress was then transcribed. It turned out that no informant was ever tempted to put stress on the first syllable of such long words (P.ant = preantepenultimate, Ant $=$ antepenultimate, Pen $=$ penultimate, Fin $=$ final):

$\begin{array}{lllll} & \text { P.ant } & \text { Ant } & \text { Pen } & \text { Fin } \\ \text { karabilo } & 0 & 1 & 18 & 1 \\ \text { monitaron } & 0 & 6 & 8 & 6\end{array}$


These data are suggestive, but one would of course need more of them to start making statistical sense. Furthermore, the fact that in a group of 20 individuals nobody puts the stress on the first four syllables, does not necessarily mean that it is disallowed on that syllable; notice that all other words in the experiment were shorter, so that the bias could even be due to some repetition effect inherent in the experimental design (people got used to putting stress on one of the last three syllables, because these were usually the only syllables available).

The second piece of information which might be relevant, although even more difficult to interpret, is the result of the experiment with (3-and 4-year-old) children. They were presented with a doll which was given a name by the researcher. This name was one of the nonsense words combined with one of the logically possible stresses. After a while, the children were asked to repeat these names, and it was recorded whether they did so correctly or not.

(8) Three-year-olds

\begin{tabular}{lllll} 
& P.ant & Ant & Pen & Fin \\
karabilo & $65 \%$ & $30 \%$ & $20 \%$ & $65 \%$ \\
monitaron & $50 \%$ & $35 \%$ & $45 \%$ & $55 \%$ \\
\multicolumn{5}{l}{ Four-year-olds } \\
P.ant & Ant & Pen & Fin \\
karabilo & $70 \%$ & $30 \%$ & $5 \%$ & $50 \%$ \\
monitaron & $60 \%$ & $35 \%$ & $65 \%$ & $55 \%$
\end{tabular}

These tables should be read in the following way. When children were asked to repeat kárabilo, 65\% of the 3-year-olds did so incorrectly; when they had to repeat karábilo, 30\% made a mistake, etc. (Only mistakes were counted that influenced the stress pattern, such as replacing the accent, or deleting certain syllables, etc.)

We have performed a similarly small online study in which informants (26 participants, all from the Netherlands, all with Dutch as their native language) were asked about the stress patterns in (Dutch versions of) biblical names. Most of these names are unknown even to many observant Jews and Christians, for instance because they occur only once in the bible. Informants got a list of approximately 50 names, and had to indicate where (main) stress should be according to their intuition. The study presented here is a pilot study, but it shows data very similar to those of Nouveau:

$\begin{array}{llllll} & \text { P.P.ant } & \text { P.ant } & \text { Ant } & \text { Pen } & \text { Fin } \\ \text { timnatcheres } & - & 42 & 0 & 42 & 3 \\ \text { parsandata } & - & 23 & 15 & 50 & 0 \\ \text { leviatan } & - & 19 & 7 & 69 & 3 \\ \text { hermogenes } & - & 7 & 46 & 38 & 0 \\ \text { benhinnomdal } & - & 3 & 69 & 11 & 3 \\ \text { akrabattene } & 19 & 3 & 23 & 42 & 0 \\ \text { apollonia } & 7 & 11 & 76 & 0 & 7\end{array}$

As a matter of fact, it turns out that in these words the preantepenultimate syllable was systematically preferred as a stress location over the final syllable, although this difference is rather small in each case. It is possible that in some of these cases the names were analysed as being compounds, which may explain then some of the stresses outside of the 
three-syllable window, but that would merely show that Dutch speakers consider long words impossible.

Obviously, these data are less supportive of the idea that Dutch has an active constraint against preantepenultimate stress, although it does show that there may be a default, or at least a preference for penultimate stress. Although children made a lot of 'errors' when having to repeat the 'impossible' pattern, they also did so for other positions, and in some cases even more so (e.g. the penultimate position on monitaron triggered more errors in four-year-olds than the preantepenultimate). Of course, also this can hardly be counted as an argument against such a constraint either; the evidence is again simply neutral. However this may be, even though a large majority of words satisfy the constraint, clear evidence for the three-syllable window as a synchronic constraint of Dutch phonology seems lacking.

\section{Quantity Sensitivity}

\section{I. SCHWA}

Another generalisation for which there is strong scholarly support in the literature is weight sensitivity. Generally, four levels of weight are distinguished: (i) schwa syllables, (ii) light syllables, (iii) heavy syllables, (iv) superheavy syllables, where the first are supposed to avoid stress altogether, whereas the last should be always stressed (Daelemans et al. 1994).

The evidence that we should distinguish schwa syllables from the rest is strong. There simply are no lexical words with a schwa syllable carrying lexical stress, although schwa can carry contrastive stress in very specific contexts:

$$
\begin{array}{llllll}
\text { Ik } & \text { zeg } & \text { geen } & \text { codá } & \text { maar } & \text { codé } \\
\text { I } & \text { don't } & \text { say } & \text { [kod'a] } & \text { but } & {[\text { kod'ə] }}
\end{array}
$$

Since such contrastive stress can basically overrule all lexical specifications, we consider this to be irrelevant for the issue at hand, except that it shows that stress on schwa is not a phonetic impossibility and therefore that the stress avoidance of schwa outside contrastive positions is a phonological fact.

As a matter of fact, Van der Hulst (1984:233) notes as a tendency that stress immediately precedes schwa, i.e. in words ending in a schwa-headed syllable, stress is on the prefinal syllable. Van der Hulst mentions the examples in (a) as an exhaustive list of 'exceptions' to this generalisation and a CELEX search yields the additional examples in (b):

(11) a. Mánchester (place name), ármoede 'poverty', Nijmegen (place name), wéduwe (widow), óórkonde (deed), Bétuwe (place name), Véluwe (place name)

b. máluwe (malva), clítoris (id), s'yfilis (syphilis), cánnabis (id), sáuriër (saurus), térriër (dog)

However, all of these are somewhat problematic. I am not sure that Manchester counts as a Dutch word; armoede and oorkonde (and possibly also Nijmegen) could count as prosodic compounds (see Section 5), the words which are spelled in $<$ is $>$ have a front vowel at least for me (and furthermore clitoris seems to have penultimate stress for many speakers); 
and the other forms (weduwe, betuwe, veluwe, maluwe, sauriër, terriër) all end in a sequence high vowel-glide-schwa, on which see e.g. Trommelen (1983), Zonneveld (1993), van Oostendorp (2000).

The line of reasoning we followed in Section 2 to disqualify the three-syllable window as a generalisation of Dutch synchronic phonology doesn't apply at least for the stresslessness of schwa, since there are no exceptions and furthermore, there is an independent indication that the relation between being unstressed and being schwa is strong in Dutch. The language has vocalic reduction. Depending on a number of factors, including the quality of the original vowel, style level of speech and the syllable structure, unstressed vowels get reduced to schwa. In particular [e] in open syllables is very sensitive to reduction, so that [e] in stressed position, and [ə] in unstressed position are almost in complementary distribution ("t Hart 1967; Booij 1976, 1982; Kager 1989; Koopmans-van Beinum 1980; van Oostendorp 2000; Zonneveld 1993). Since there are alternations and these are triggered by stress, the connection between metrical weakness and being schwa seems to be a real fact of Dutch synchronic phonology.

\subsection{LIGHT AND HEAVY SYLLABLES}

The distinction between light and heavy syllables is a little bit more controversial. We could raise two issues. ${ }^{6}$ First, the definition of the distinction is somewhat unusual. Secondly, we could wonder whether we need to refer to the distinction at all.

The definition issue is the following one. Disregarding schwa, Dutch has two sets of vowels: tense vowels, which only occur in open syllables, and lax vowels, which only occur in closed syllables. ${ }^{7}$ According to some authors (for instance, Zonneveld 1993; Kooij and van Oostendorp 2004), this phonotactic pattern can be described by assuming that the tense vowels are phonologically long - many of them are so phonetically as well, although the high tense vowels are not - and furthermore that every Dutch syllable is minimally bimoraic. This implies that there are basically two types of syllables in Dutch: $\mathrm{C}(\mathrm{C}) \mathrm{VV}$ and $\mathrm{C}(\mathrm{C}) \mathrm{VC}$. The curious thing is, however, that the available evidence seems to point in the direction of CVV being light and CVC being heavy. This is quite unexpected: existing typologies of syllable weight would predict that it is the opposite. $^{8}$

The evidence in favour of a heavy-light distinction in Dutch is a little bit subtle, to say the least. I will discuss two types of evidence. In Section 3.3 I will turn to putative evidence that the distinction plays a role in the calculation of secondary stress. Here, I concentrate on the special role of the penultimate syllable. Many authors have pointed to the generalisation in (12):

(12) When the penultimate syllable is heavy, stress cannot be on the antepenultimate.

$$
\text { Agénda, fricandéau, *ágenda, *frícandeau }
$$

A careful study based on a word list is provided by Van der Hulst (1984). Assuming that tense vowels are long, Van der Hulst reports zero words with initial stress for trisyllabic words of the shapes in (14a); if the penultimate syllable is open, on the other hand, we do find cases with initial stress. After each pattern we give two numbers; the first is the number of words in Van der Hulst's data which had initial stress, 
the second the total number of words with the relevant syllable profile (Van der Hulst 1984:223):

(14) a. No initial stress when penultimate syllable is closed: VC-VC-VC (0/15), VC-VC-VV (0/28), VV-VC-VC (0/19), VV-VC-VV (0/54)

b. Initial stress when penultimate syllable is open: $\mathrm{VC}-\mathrm{VV}-\mathrm{VV}(21 / 72)$, VV-VV-VV (59/182), VV-VV-VC (60/115), VC-VV-VC (40/66)

However, a CELEX search shows counterexamples for each of the classes in (14a) that are supposed to be impossible:
a. 'VC. VC. VC
mangistan, badminton
b. 'VC. VC. VV
chimpanzee
c. 'VV.VC.VV
shoarma
d. (VC).'VV.VC.VC
sanniyasin

I have to add to this that many native speakers in an informal survey put stress on the heavy syllable in both (c) and (d), so that we could possibly say that words with a heavy penultimate and a light antepenultimate syllable never have stress on the latter; but I know of no theory which could make this particular prediction. (Also, it is clear that the penultimate syllable is a default location for stress, also if it is light.)

The following graph shows the differences between stress patterns in words with an open (blue line) and closed (red, dashed line) penultimate syllable. It can be clearly seen that in both cases, there is a strong tendency to put stress on that penultimate syllable. For heavy syllables we find less stress on other positions, but this is true both for the antepenultimate and the ultimate syllable:

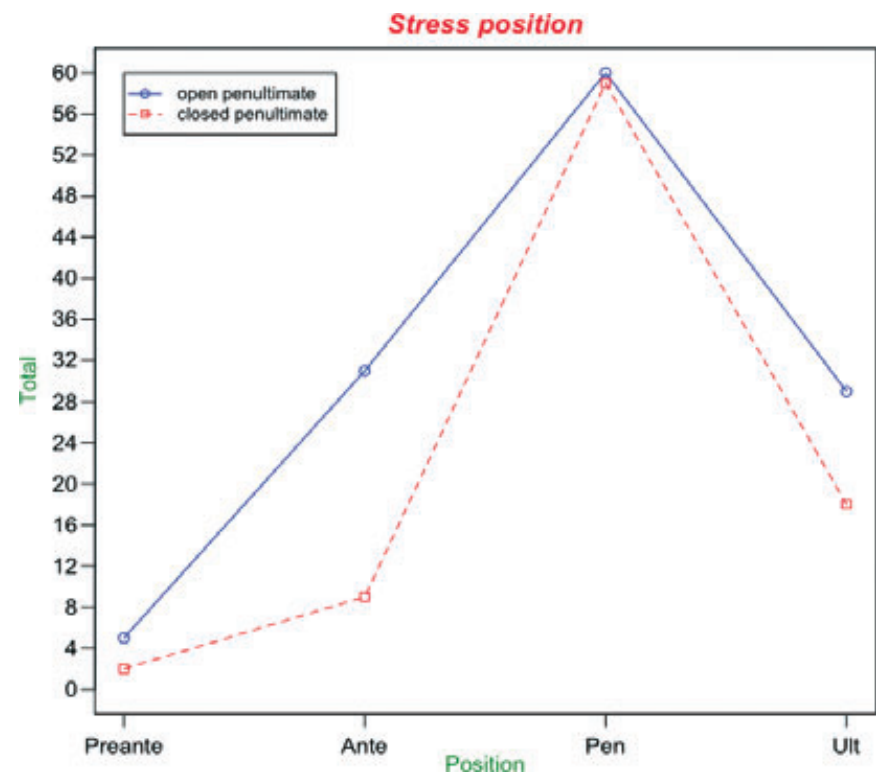


The difference between open and closed penultimate syllables is of course still significant, but it seems to me that neither chimpanzee nor badminton sounds very eccentric to the average Dutch ear.

According to most authors (Van der Hulst 1984; Trommelen and Zonneveld 1989; Kager 1989; Nouveau 1994), weight is visible on the final syllable as well, albeit in a slightly more complicated way: in words of the shape VX-VV-VC there is a preference for initial stress over penultimate stress, which may be caused by the fact that the latter two syllables do not form a good trochee together. This is confirmed by the following graph, based again on a CELEX search:

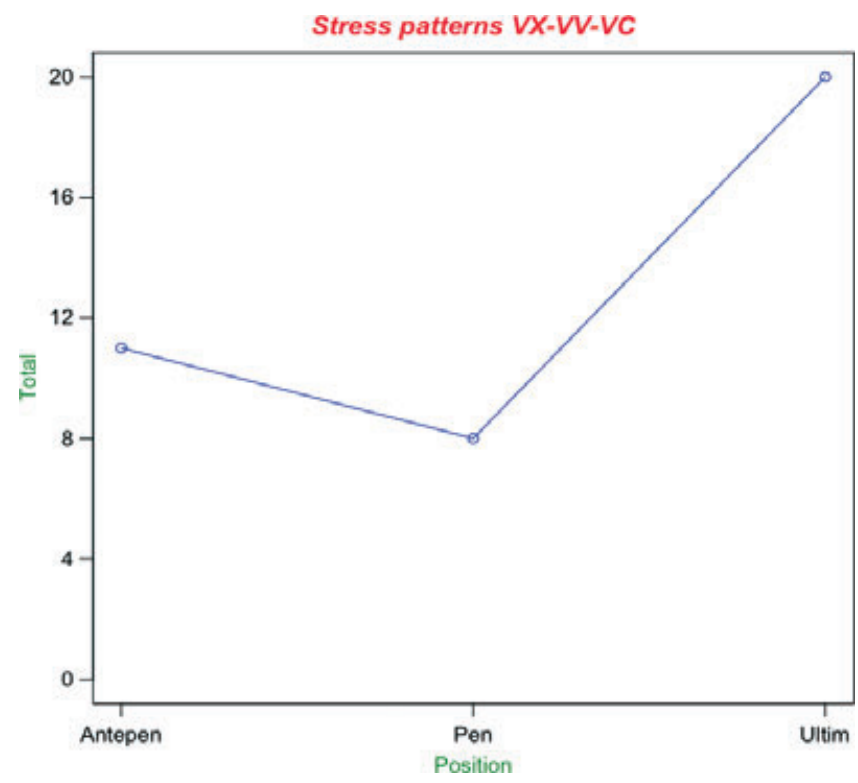

However, this graph also shows that the other two stress patterns are also possible for words of this type (as a matter of fact, there are even more cases of stress on the final syllable), and it is not clear what to make of that.

Furthermore, it is not clear to what extent a language learner needs to know the generalisations in (10) in any relevant sense of the word 'to know', since this type of weight sensitivity is present also in the most common source languages for loanwords.

On the other hand, there is some evidence that stress patterns violating (12) are treated as marked by the language users: they tend to undergo regularization. This evidence again comes from experiments with nonsense words. Nouveau's (1994) test with adults contained four three-syllabic words with a heavy penultimate syllable. As before, we indicate the number of informants who assigned initial stress, and the total number of renditions of the word:

$$
\begin{array}{ll}
\text { ka-nak-ta } & (0 / 20) \\
\text { ma-rot-ko } & (0 / 20) \\
\text { ta-lak-tan } & (2 / 20) \\
\text { ba-ral-ton } & (6 / 20)
\end{array}
$$

At least in the final case the number of responses which gave initial stress were 1:3, i.e. at chance level (since there were three syllables). Furthermore, in the first two examples (in 
which the final syllable is open), the fact that there were no stresses on the initial syllable might be related to the fact that nobody stressed the final syllable in these cases either: everybody said kanákta and marótko. A further point to note is that the example which does show final stress is the only one in which the penultimate is closed by a sonorant, which should count as the 'heaviest' of consonants.

Zonneveld (2003) did a similar experiment with a group of 44 students, and found the patterns such as the following:

$\begin{array}{lllll}\text { a. } & \text { to-gar-ma } & 4 & 39 & 1 \\ \text { te-man-do } & 3 & 40 & 1 \\ \text { b. } & \text { po-tran-dat } & 7 & 22 & 15 \\ \text { tri-men-tok } & 13 & 20 & 11\end{array}$

Zonneveld (2003) concludes from this that antepenultimate stress is impossible on words ending in a VC-VV pattern. This is indeed something that seems to arise from these experimental data, but as far as I can see it does not take into account the real words chimpanzee and (possibly) shoarma.

It thus seems fair to say that there are several statistical tendencies in the lexical material, which are partly to be related to weight. The very scarce test data we have indicates that at least some of these tendencies are reflected in informants' response to nonsense words, but these do not reflect very hard facts: there is always variation. Clearly, much more experimental work is needed here, but in the absence of this, I would conclude that there is little reason why analysts have been so uniform in their adoption of the assumption that Dutch stress is quantity-sensitive; an alternative analysis seems also feasible.

\subsection{QUANTITY IN SECONDARY STRESS}

In the literature we find some suggestions that secondary stress might be sensitive to syllable weight as well. Dutch has a productive process of vowel reduction to schwa in unstressed position (Booij 1976, 1982; Kager 1989; van Oostendorp 2000; Geerts 2008), which however is sensitive to a number of factors, such as word frequency and vowel height which we will not be concerned with here.

One position where we might see this at work is in the analysis of words of four syllables of which the last one has primary stress. The first syllable in such words will carry secondary stress. The other two syllables will both be subject to (optional) reduction when they are open:

$\begin{array}{lll}\text { temperatuur } & \text { ['temp rə'tyr] } & \text { 'temperature' } \\ \text { fonologie } & \text { ['fonələ'ri] } & \text { 'phonology' } \\ \text { individu } & \text { ['Indəvə'dy] } & \text { 'individual' }\end{array}$

A few things should be noted about these examples. First, these forms sound very informal with reduction, and that is a bit unnatural since long words such as these usually belong to the learned lexicon. Secondly, the two positions are different in an interesting way: reduction of the second unstressed position (the one in the third syllable of the word) implies reduction in the first unstressed position (in the second syllable of the word). Thus, ['fonəlo'ri] is possible, but *['fonolə'ri] is not. 
However, things change when the second syllable is closed, according to Trommelen and Zonneveld (1989:119):

\begin{tabular}{|c|c|}
\hline $\begin{array}{l}\text { constantinopel } \\
\text { testosteron } \\
\text { conservatief }\end{array}$ & $\begin{array}{l}\text { [konstantə'nopəl] } \\
\text { [tEstวstə'ron] } \\
\text { [kənsErva'tif] }\end{array}$ \\
\hline
\end{tabular}

Trommelen and Zonneveld (1989) take these data as an argument that the prosodic structures of (12) and (13) are different: the closed second syllables in (13) are heads of secondary stress feet, but the open second syllables in (12) are not. A general rule reducing vowels then treats the two positions differently. (Similar claims have been made for English by Ross 1972).

This is not the only option we have, however. Van Oostendorp (1995) suggests that it is rather the reduction rule which is sensitive to syllable structure. The reason is that schwa seems to avoid closed syllables also when it is not the result of reduction. For instance, underlying schwa can not be followed by any (non-coronal) obstruent either. Furthermore, Booij (1995) notices that reduction is possible in some cases under the condition that the coda consonant is deleted at the same time. But if the reduction rule is sensitive to the absence or presence of a coda, there is no more reason to assume that secondary stress placement is.

\section{Superheavy Syllables}

The last category of syllable weight seems a bit less controversial. Superheavy syllables - consisting of a tense vowel followed by a consonant or a lax vowel followed by at least two consonants - are very strong attractors of word stress. They typically occur at the end of the word, and if they do, they are often stressed (Van der Hulst 1984:217):

$$
\text { olijf 'olive', vióól 'violin', citróén 'lemon', alárm 'alarm', protést 'protest' }
$$

However, this generalisation is not exceptionless:

króépoek 'krupuk, prawn crackers', árbeid 'labour', vámpier 'vampire', nónsens 'nonsense', ámbacht 'craft', ásbest 'asbestos', lichaam 'body'

Such words have been analysed as prosodic compounds by Trommelen and Zonneveld (1989:160), i.e. as words which have the prosodic structure of compounds in spite of the fact that neither of the constituent parts occurs as an independent word (or in many cases even as a part in any other compound); in other words, they are seen as compounds which consist of two cranberry-morphs. Compound stress in Dutch is on the first member of the compound, at least for nouns (Booij 1995).

Trommelen and Zonneveld (1989) make a few observations supporting a prosodic compound analysis, of which we will mention two. The first is that cranberry-morphs are typically monosyllabic in Dutch, and the exceptional patterns such as those in (15) are almost all bisyllabic. ${ }^{10}$ The second concerns the suffixes -elijk and -ig. Trommelen and Zonneveld (1989) state: 
(22) These specific suffixes will normally get attached to base words which have one of the following properties: final stress (including monosyllabic words [...]); or compound.

Thus the adjectivising suffix - elijk can be attached to fatsóén ('decency'; stress final) and stáátsrecht (constitutional law) to derive fatsóénlijk and staatsréchtelijk (notice that stress shifts in the latter case), but not to únie (union) with penultimate stress (*únielijk, *uní́lijk). Interestingly, on the other hand the suffix can be attached to lichaam 'body' to derive lichámelijk 'physical' (with stress shift). Since líchaam clearly is not monosyllabic, it follows from the classification in (16) that it is a compound.

Neither of Trommelen and Zonneveld's (1989) arguments may be completely compelling. The observation that cranberry-morphs tend to be monosyllabic is in itself unexplained; and suffixation with -elijk (or -ig) is not productive in Dutch (De Haas and Trommelen 1993). However, taken together, and with the observation that apart from some bisyllabic cases there seem to be no words ending in unstressed superheavy syllables, the indications seem to be quite strong that the notion of superheavy syllable does play a role in the analysis of Dutch.

\section{Discussion: Is Dutch Stress Sensitive to Quantity?}

We can thus see that there are various statistical tendencies to be shown in the Dutch lexicon. The strongest among these is probably a preference for penultimate stress, which for instance has resulted in stress shifts such as notúlen 'minutes' (from nótulen) en catalógus 'catalogue' (from catálogus).

Based on previous literature, the evidence for the role of quantity is somewhat paradoxical. This literature, as summarized above, assumes that there is a four-way scale of weight for Dutch syllables: $\mathrm{C}(\mathrm{C})<\mathrm{CV}(\mathrm{V})<\mathrm{CVC}<\mathrm{CVVC}$, CVCC. We have seen that the evidence is rather strong for the lower end of the scale as well as for the higher end, i.e. that schwa syllables are really weaker and superheavy syllables are really stronger than other syllables. The evidence for a 'core' distinction between heavy and light syllables is much weaker however. This is a rather curious state of affairs, and in need of an explanation.

One direction to go would be to distinguish two types of quantity sensitivity. Traditionally, sensitivity to quantity implies counting rhyme positions or moras: those segments with two such positions are heavy, those without two such positions are light. I would argue that Dutch grammar does not possess this type of counting mechanism.

In the case of schwa, the weightlessness issue seems a bit different: both open and closed schwa syllables count as extra light. It does not seem to be the quantity of segments but rather the quality of the head which counts. ${ }^{12}$ I propose that Dutch has the quality type of weight-sensitivity, but not the quantity type. The relevant generalisation is the one in (23):

Syllables with an empty head should occur in the weak position of a trochee.

The intuition behind this is that weak metrical positions should not contain too much phonological material, and inversely. ${ }^{13}$ One could debate about the precise definition of 'emptiness', but it does not seem unreasonable to say that schwa is heavily 
underspecified, at least in Dutch, where it functions as an epenthetic vowel and as the output of vowel reduction (Booij 1995; van Oostendorp 2000). It is thus empty in a relative sense.

The claim in (17) can then be generalized to superheavy syllables. Following McCarthy's (1979) analysis of Arabic stress, Langeweg (1988) proposes that superheavy syllables consist of a 'normal' syllable followed by an extra consonant. In Zonneveld (1993) this same idea is formalised as assuming that superheavy syllables are bisyllabic complexes of which the second syllable consists of an onset consonant only. The previous syllable can be a closed syllable with a lax vowel or an open syllable with a tense (possibly long) vowel. This thus implies that there is a one to one correlation between being tense and being in an open syllable, on which see van Oostendorp (2000), Botma and van Oostendorp (Ms). Because the second syllable clearly counts as an empty headed syllable, it should be subject to (23). That is the reason why the preceding syllable (which contains the audible nucleus of the 'superheavy' complex) attracts stress.

If we take these two ideas together, we can thus generalize over the behaviour of schwa syllables and the 'extra consonant' of superheavy syllables. ${ }^{14}$ Both of them involve emptiness in some sense, and both of them are sensitive to (23) in Dutch. Seen in this way, Dutch has no quantity sensitivity in the traditional sense of the word. It has quantity-insensitive trochees with as its only extra restriction that 'empty' vowels should occur in the weak position of a foot (it thus is rather quality-sensitive in some way). ${ }^{15}$

The claim that Dutch is not quantity-sensitive does not mean that the stress system does not interact with syllable structure at all. Gussenhoven (2009) shows that stressed tense vowels lengthen. He analyses this within a theory which basically assumes quantity-sensitivity, but we can readily understand the fact without such an assumption. We find lengthening of stressed vowels in open syllables also e.g. in Italian, a language for which there is little evidence of quantity sensitivity (Krämer 2009). In terms of Optimality Theory, we may say that faithfulness to underlying length of tense vowels is irrelevant, and length is determined exclusively by constraints regulating the interaction with stressed positions. Furthermore, it should be noted that weight considerations clearly play a role in the Dutch lexicon in the form of tendencies as we have seen above. In this context, the findings of Daelemans et al. (1994) become relevant. In a 'data-oriented' study, these authors showed that machines can acquire the stress pattern of Dutch with a reasonable amount of succes, and that this success is bigger when information is provided on the weight of syllables. Unfortunately, Daelemans et al. worked with a scale which just ran from 'superlight' (=schwa) to 'superheavy' without discriminating the various sources of weight which we established above. (Also, much to their own surprise, they found a small quality effect, not otherwise discussed here: syllables with [e] tended to attract more stress than would be expected given they positions they were in. One reason behind this effect is that /e/ is particularly prone to schwa reduction; thus, whenever we find an unreduced [e] we can be rather sure that we are dealing with a stressed vowel.)

Since these tendencies themselves ultimately may find an explanation in the source languages from which Dutch has extensively borrowed, there may not be a reason to incorporate them into the phonological grammar. The extensive work which Dutch phonologists did in the 1980s and 1990s has definitely uncovered many interesting statistical generalisations, which need to be explained - but maybe they were not always about the phonological knowledge of a native speaker. 


\section{Short Biography}

Marc van Oostendorp (Rotterdam, The Netherlands, 1967; MA in Linguistics, Tilburg University, 1991; PhD, Tilburg University, 1995). Currently employed at Meertens Institute/Royal Netherlands Academy of Arts and Sciences (Senior Researcher; since 1999) and Leiden University (Professor of Phonology; since 2008). Previous employers include the University of Amsterdam. Academic Prizes and Awards include the AVT/Anéla Dissertation Price for the best linguistics dissertation in the Netherlands (1996), and the LOT Oeuvre Prize for Popularisation of Linguistics (2007). He serves on the Editorial Boards of the journals Phonology (CUP) and Language Problems and Language Planning (Benjamins).

\section{Acknowledgement}

I wish to thank my colleagues Geert Booij, Ben Hermans, Björn Köhnlein and Willem Visser for enlightening discussion. Furthermore, this paper has been considerably benefited from some comments of two anonymous reviewers. All usual disclaimers apply.

\section{Notes

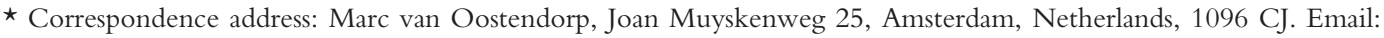 marc.van.oostendorp@meertens.knaw.nl}

1 A reviewer points out that in his view the mentalistic claim of generative phonology should not be taken too seriously, and phonologists describe the patterns which they find. The claim of this paper is not just that the mentalistic claim should be taken more seriously - by eliminating complexities from the Dutch system which do not belong there we also gain insight in what is a possible phonological system - but also that many of the 'patterns' are less than real: they describe statistic tendencies at best.

2 CELEX (http://celex.mpi.nl/) is a huge database with Dutch words, based on a number of balanced corpora of written Dutch. For this article, I have used the section 'Dutch lemma's' and selected only the monomorphemic words.. Morphology interacts with stress in a very interesting way in Dutch, but that is not the topic of this paper.

3 One convincing argument for trochaic foot which is not directly based on stress, but rather on an intonational phenomenon called the 'chanted call', can be found in Gussenhoven (1993).

4 We will just assume trochaic feet, so that the constraint disallowing iambs is not needed in the tableaux.

5 In this example, the form with only one foot wins, because of the relative ranking of Stress-rightmost and Parsesyllable. We could also reverse the ranking, in which case (b) would win, which is phonetically equivalent. Since this is a sample analysis, there is no reason to go into this discussion here.

6 Booij (1995:101, fn. 8) is one of the few recent sources who cast doubt on the weight sensitivity of Dutch stress.

7 The generalisation as described here is true word internally. At the edges of word, we can have at most one extra non-coronal consonant, so that final tense vowels can be in a syllable closed by one, and lax vowels in a syllable closed by two consonants. Furthermore, one or more voiceless coronal obstruents $(s$ or $t$ ) can follow this complex.

8 This problem can be solved under an alternative view of syllable structure and its relation to segmental phonology which has it that phonologically tense and lax vowels are all short, the only relevant distinction being one which is described by a feature such as [tense], [lax] or [ATR], so that Dutch has two types of syllables, of which CV would be light and CVC would be heavy (van Oostendorp 2000).

9 Although this is orthogonal to the discussion, I note that I do not personally agree with these judgements. In particular, I would never pronounce conservatief in the way indicated, but rather as [kənsərvatif] or, in the ultimate case, [konsərvatif]. The reason for this could be that the schwa in the second syllable is underlying for speakers like me, and not the result of reduction. I agree with the other judgements.

10 Trommelen and Zonneveld do not mention exceptions; Van der Hulst (1984) mentions 'an almost total absence of exceptions' to the rule that in trisyllabic words ending in a superheavy syllable the last syllable is stressed, but does not mention any of the exceptions which he suggests might exist. I suppose 'olifant 'elephant' is one of these.

11 Deze specifieke suffixen hechten normaal aan aan grondwoorden die een van de volgende eigenschappen hebben: eindklemtoon (inclusief monosyllabisch, en met schwa in de laatste lettergreep; of geprefigeerd); of samengesteld (Trommelen and Zonneveld 1989:164).

12 But see Kager (1989) for arguments that the lightness of schwa should be attributed to it being moraless. 
13 Similar ideas were expressed in Moortgat and Van der Hulst (1981), Zonneveld (1993) and van Oostendorp (1995, 1997).

14 A reviewer points out that Trommelen (1983) has already drawn a connection between superheavy syllables and schwa syllables. Notice, however, that this connection is a little bit different in Trommelen's (1983) work: there, it is pointed out that tense vowels and schwas both can be followed by either nothing or at most one non-coronal consonant, whereas lax vowels can be followed by one or two non-coronal consonants. (In both cases, more voiceless coronal plosives may follow.)

15 Another way in which they might be considered quantity sensitive is the special behaviour of high vowels that seem to avoid stress. Note that many of the 'problematic' cases in (11) have a high vowel in the position where one would regularly expect stress. Another case which might show the same is the contrast between the names Unicef (stress on the first syllable) and Unesco (stress on the regular penultimate syllable).

\section{Works Cited}

Booij, Geert. 1976. Klinkerreductie in het Nederlands. Leuvense Bijdragen 65. 461-70.

1982. Fonologische en fonetische aspecten van klinkerreductie. Spektator 11. 295-301.

1995. The phonology of Dutch. Oxford: Oxford University Press.

Botma, Bert, and Marc van Oostendorp. Ms. A propos of the Dutch vowel system 21 years on, 22 years on, Leiden University.

Daelemans, Walter, Steven Gillis, and G. Durieux. 1994. The acquisition of stress. A data-oriented approach. Computational Linguistics 20(3). 421-51.

De Haas, Wim, and Mieke Trommelen. 1993. Morfologisch handboek van het Nederlands. The Hague: Sdu.

Don, Jan, and Wim Zonneveld. 1988. CV Phonology. Theory and machine in Dutch stress assignment. PRIPU 13. 8-32.

Ernestus, Mirjam. 2000. Voice assimilation and segment reduction in casual Dutch. Utrecht: LOT.

Geerts, Twan. 2008. More about less. Fast speech phonology: the cases of French and Dutch. Radboud Universiteit Nijmegen: PhD Dissertation.

Gussenhoven, Carlos. 1993. The Dutch foot and the chanted call. Journal of Linguistics 29. 37-63.

—. 2009. Vowel duration, syllable quantity, and stress in Dutch. The nature of the word. Essays in honor of Paul Kiparsky, ed. by Kristin Hanson and Sharon Inkelas, 181-98. Cambridge, MA/London, UK: MIT Press.

Hammond, Michael. 1999. The phonology of English. A prosodic-optimality theoretic approach. Oxford: Oxford University Press.

Hart, Johan 't. 1976. Fonetische steunpunten. De Nieuwe Taalgids 62. 168-74.

— - and Michael Moortgat. 1981. Prosodische fonologie en de accentuatie van Nederlandse woorden, of: Leeft het Nederlands op grote voet. Verslag van de 150e vergadering van de Nederlandse vereniging van fonetische wetenschappen. Amsterdam. 1-25.

Kager, René. 1989. A metrical theory of stress and destressing in English and Dutch. Dordrecht: Foris.

— and Ellis Visch. 1983. Een metrische analyse van ritmische klemtoonverschijnselen. Utrecht: MA thesis.

— - - and Wim Zonneveld. 1987. Nederlandse woordklemtoon (hoofdklemtoon, bijklemtoon, reductie, voeten). GLOT 10. 197-226.

— , and Wim Zonneveld. 1986. Schwa, syllables and extrametricality in Dutch. The Linguistic Review 5. 197221.

Kooij, Jan G. 1978. Aksentregels en syllabestruktuur in het Nederlands. De Nieuwe Taalgids 71. 543-8.

_ , and Marc van Oostendorp. 2004. Fonologie. Uitnodiging tot de klankleer van het Nederlands. Amsterdam: AUP.

Koopmans-van Beinum, Florien. 1980. Vowel contrast reduction. An acoustic and perceptual study of Dutch vowels in various speech conditions. University of Amsterdam: $\mathrm{PhD}$ dissertation.

Krämer, Martin. 2009. The phonology of Italian. Oxford: Oxford University Press.

Lahiri, Aditi, and J. Kooreman. 1988. Syllable weight and quantity in Dutch. WCCFL 7. 217-28.

Langeweg, Simone. 1988. The stress system of Dutch. Leiden University: PhD dissertation.

van Marle, Jaap. 1980. The stress pattern of Dutch simplex words. A first approximation. Studies in Dutch phonology, ed. by Wim Zonneveld, Frans van Coetsem and O. W. Robinson, 79-121. The Hague: Nijhoff.

Martin, W. 1968. De verdoffing van gedekte en ongedekte e in niethoofd-tonige positie bij Romaanse leenwoorden in het Nederlands. De Nieuwe Taalgids 61. 162-81.

McCarthy, John. 1979. On stress and syllabification. Linguistic Inquiry 10. 443-66.

Neijt, Anneke, and Wim Zonneveld. 1982. Metrische fonologie. De representatie van klemtoon in Nederlandse monomorfematische woorden. De Nieuwe Taalgids 75. 527-47.

Nouveau, Dominique. 1994. Language acquisition, metrical theory, and optimality. A study of Dutch word stress. Utrecht University: PhD dissertation.

van Oostendorp, Marc. 1995. Vowel quality and syllable projection. Tilburg University: PhD dissertation. 1997. Lexicale variatie in de optimaliteitstheorie. Nederlandse Taalkunde 1997. 13-145. 
2000. Phonological projection. Berlin: Mouton De Gruyter.

Rietveld, Toni, Joop Kerkhoff, and Carlos Gussenhoven. 2004. Word prosodic structure and vowel duration in Dutch. Journal of Phonetics 32. 349-71.

Ross, John R. 1972. A reanalysis of English word stress. Contributions to generative phonology, ed. by M. Brame, 231-45. Austin and London: University of Texas Press.

Trommelen, Mieke. 1983. The syllable in Dutch. With special reference to diminutive formation. Dordrecht: Foris.

—. 1989. Lettergreepstructuur en woordcategorie. De Nieuwe Taalgids 82. 64-77.

1991. Dutch word stress. Extrametricality and feet. The Berkeley Conference on Dutch Linguistics 1989. Issues and Controversie, ed. by T. F. Shannon and J. P. Snapper, 157-73. Lanhan: University Press of America. —

, and - 1999. Word stress in English and Dutch. Word prosodic systems of the languages of Europe, ed. by H. van der Hulst, 132-3. Berlin: Mouton de Gruyter.

Van der Hulst, Harry. 1984. Syllable structure and stress in Dutch. Leiden University: PhD Dissertation.

Visch, Ellis. 1989. The rhythm rule in English and Dutch. Utrecht: Proefschrift.

- and René Kager. 1984. Syllable-weight and Dutch word stress. Linguistics in the Netherlands, ed. by Hans Bennis and Wus van Lessen Kloeke, 231. Dordrecht: Foris.

Visser, Willem. 1997. The syllable in frisian. The Hague: Holland Academic Graphics.

Wiese, Richard. 2000. The phonology of German. Oxford: Oxford University Press.

Zonneveld, Ron van. 1982. Met de ritmische hangmat in de metrische boom. Tabu 12. 65-85.

- 1984. Word rhythm and the Janus syllable. The structure of phonological representations II, ed. by Harry van der Hulst and Norval Smith, 133-40. Dordrecht: Dordrecht-Foris.

Zonneveld, Wim. 1993. Schwa, superheavies, stress and syllables in Dutch. The Linguistic Review 10. 61-110.

- 2003. Zijn er op vooruit gegaan in de fonologie? Fonologische kruispunten. Studies op het gebied van de Nederlandse taalkunde, ed. by Georges de Schutter and Steven Gillis, 24. Gent: KANTL. 